\title{
Pertumbuhan Ekonomi Indonesia Perspektif Ekonomi Islam: Peran Inflasi, Pengeluaran Pemerintah, Hutang Luar Negeri dan Pembiayaan Syariah
}

\author{
Eny Widiaty ${ }^{1 *}$, Anton Priyo Nugroho ${ }^{2}$ \\ ${ }^{1,2}$ Magister Ilmu Agama Islam, FIAI, Universitas Islam Indonesia \\ *Email Korespondensi: eny.widiaty0123@gmail.com
}

\begin{abstract}
Economic growth is a fundamental indicator in assessing economic performance. In assessing the economic growth, it can use several important variables such as Inflation, Government Consumption Expenditure, Foreign Debts, and Sharia Finance. In turn, this research aims to analyze the impacts of these variables on the economic growth in Indonesia (Quarter I - Quarter IV) in the period of 2011-2018. The Error Correction Model used in the analysis method. The results of the analysis showed that the variable inflation in the longterm harmed economic growth; while, in the short-term, the level of inflation had a positive impact on economic growth. Meanwhile, the variable of Government Consumption Expenditure had a negative contribution to economic growth. Furthermore, foreign debt in the long term hurt economic growth, but for the short term, it could bring the positive one. Variable of Sharia finance showed a good result both in the short term and in the long term with a negative correlation with economic growth in Indonesia. However, all variables of inflation, Government Consumption Expenditure, foreign debts, and sharia finance simultaneously had an impact on National Economic Growth.
\end{abstract}

Keywords: Economic Growth, Inflation, Government Consumption Expenditure, Foreign Debt, Sharia Finance.

Saran sitasi: Widiaty, E., \& Nugroho, A. P., (2020). Pertumbuhan Ekonomi Indonesia Perspektif Ekonomi Islam: Peran Inflasi, Pengeluaran Pemerintah, Hutang Luar Negeri dan Pembiayaan Syariah. Jurnal Ilmiah Ekonomi Islam, 6(02), 223-238. doi:http://dx.doi.org/10.29040/jiei.v6i2.1043

DOI: http://dx.doi.org/10.29040/jiei.v6i2.1043

\section{PENDAHULUAN}

Pertumbuhan ekonomi dalam analisa ekonomi makro menjadi salah satu parameter yang sangat esensial, dalam perspektif yang luas pertumbuhan ekonomi menunjukkan bagaimana aktivitas ekonomi dapat melahirkan perubahan dalam struktur sosial masyarakat yang akan menghasilkan tambahan pendapatan dan kesejahteraan. Meningkat atau tidaknya laju pertumbuhan ekonomi dapat dilihat dari realisasi pembangunan yang telah terlaksana (Romi \& Umiyati, 2018).

Teori pertumbuhan ekonomi tidak hanya dikaji dalam literatur konvensional, tapi juga ditemukan dalam konsep ekonomi Islam, di mana Islam menjadikan kesejahteraan sebagai tolok ukur dalam menentukan suatu pertumbuhan. Namun di dalam Islam, peningkatan yang terjadi pada perekonomian tidak dianggap sebagai pertumbuhan apabila barangbarang yang diproduksi terbukti mengancam keselamatan manusia (Muttaqin, 2018).
Badan Pusat Statistik (BPS) merilis data pertumbuhan ekonomi Indonesia tahun 2011-2018 mengalami fluktuasi. Pada triwulan IV tahun 2018 ekonomi Indonesia tumbuh sebesar 5,18 persen melenceng dari target yang ditetapkan sebesar 5,4 persen, meski demikian dipaparkan oleh BPS bahwa pertumbuhan ekonomi Indonesia tahun 2018 terjadi pada seluruh lapangan usaha. Namun jika dibandingkan dengan triwulan IV tahun 2017, pertumbuhan ekonomi Indonesia tahun 2018 menurun 1 persen dari tahun 2017 yaitu sebesar 5,19 persen. Sementara pertumbuhan ekonomi triwulan IV tahun 2016, 2015, dan 2014 juga masih berkisar 5 persen akan tetapi masih lebih rendah dari tahun 2017 dan 2018. Indonesia pernah mengalami pertumbuhan ekonomi hingga 6,50 persen pada triwulan IV tahun 2011 dan merupakan pertumbuhan ekonomi tertinggi selama periode 8 tahun terakhir. 


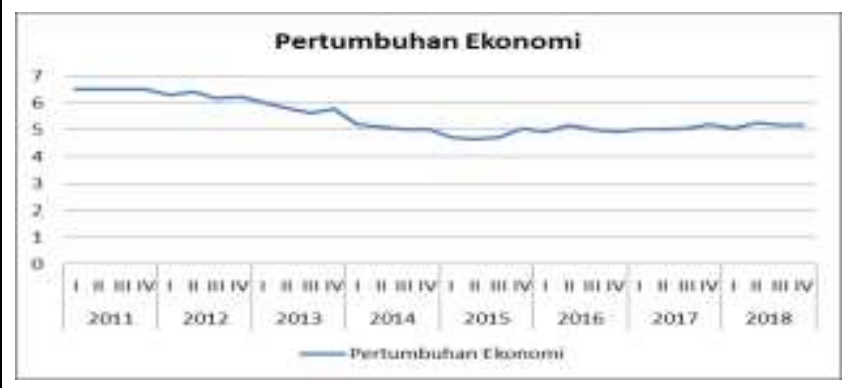

Gambar 1. Grafik Pertumbuhan Ekonomi Indonesia 2011-2018

Sumber: BPS, Statistik Indonesia diolah, 2019

Dalam perkembangannya pertumbuhan ekonomi dari beberapa tahun mengalami naik turun salah satunya dipengaruhi oleh permintaan agregat. J.M.Keynes dalam teorinya mengatakan bahwa dalam jangka pendek output nasional dan kesempatan kerja ditentukan oleh permintaan agregat. Permintaan agregat sendiri dipengaruhi oleh harga sesuai dengan hukum permintaan di mana jika harga naik maka permintaan turun. Kebijakan moneter maupun kebijakan fiskal menurut kaum Keynesian dapat digunakan sebagai solusi untuk mengatasi pengangguran dan menurunkan laju inflasi (Ardiansyah, 2017).

Inflasi merupakan fenomena yang kerap terjadi dalam struktur ekonomi. Selain diungkapkan oleh teori-teori konvensional, permasalahan inflasi juga menjadi perhatian penting oleh para ahli ekonomi Islam salah satunya adalah Al-Maqrizi. Menurutnya, inflasi terjadi karena neningkatnya harga-harga secara yang berlangsung secara terus menerus. Pernyataannya didukung dari berbagai fakta bencana kelaparan yang pernah terjadi di Mesir, di mana inflasi yang terjadi secara terus menerus mengakibatkan penurunan daya beli masyarakat yang berdampak pada penurunan perekonomian negara (Fadilla, 2017).

Diketahui laju inflasi Indonesia selama delapan tahun terakhir yaitu tahun 2011-2018 cenderung berfluktuasi sejalan dengan pertumbuhan ekonomi Indonesia yang mengalami fluktuasi. Inflasi tertinggi terjadi pada triwulan IV tahun 2014 sebesar 2,46 persen dan terus mengalami penurunan hingga tahun 2018. Diketahui pada triwulan IV tahun 2018 terjadi inflasi sebesar 0,62 persen. Inflasi ini secara simulkan disebabkan oleh naiknya seluruh indeks kelompok pengeluaran, di antaranya kelompok bahan makanan, makanan jadi, minuman, rokok dan tembakau. Juga oleh perumahan, air, listrik, gas dan bahan bakar. Di samping itu kelompok pendidikan, rekreasi dan olah raga, srta transportasi, komunikasi, dan jasa keuangan ikut serta memicu terjadinya inflasi.

Tidak hanya inflasi, pertumbuhan ekonomi yang dijadikan barometer suatu negara juga tidak bisa lepas dari peran pemerintah. Pemerintah dalam hal ini sebagai fasilitator dalam berbagai kegiatan pembangunan baik bidang ekonomi maupun non ekonomi. Untuk mengaktualisasikan pembangunan tersebut diperlukan dana yang tidak sedikit, maka dari itu pemerintah telah merumuskannya dalam rancangan pengeluaran negara. Menurut Sodik (2007), jumlah pengeluaran pemerintah yang proporsional akan berdampak pada meningkatkan pertumbuhan ekonomi (MS, 2017).

Masalah pengeluaran pemerintah merupakan bagian dari kebijakan fiskal negara. Adapun kebijakan fiskal sebenarnya sudah dikenal yaitu sejak zaman Rasulullah SAW dan Khulafaur Rasyidin, serta kemudian dikembangkan lebih lanjut oleh para ulama yaitu terkait penerimaan negara dan sumber pengeluaran negara. Alokasi pengeluaran dalam negara Islam dipusatkan untuk kegiatan yang berkenaan pada pengetahuan keIslaman dan meningkatkan kesejahteraan rakyat. Sedangkan pendapatan pemerintah harus secara merata didistribusikan kepada rakyat (Gempito, 2010).

Dapat dilihat dalam publikasi BPS data realisasi pengeluaran konsumsi Pemerintah di Indonesia tahun 2011-2018 mencatat kenaikan dari tahun ke tahun. Hingga triwulan IV tahun 2018 jumlah pengeluaran konsumsi Pemerintah sebesar 828,7 triliun rupiah. Besarnya pengeluaran konsumsi Pemerintah tahun 2018 karena banyaknya pembangunan infrastruktur yang dilakukan, seperti dalam mendukung ketahanan air dan pangan. Pemerintah pada tahun 2018 telah selesai membangun 8 bendungan yaitu Bendungan Paya Seunara dan Rajui di Aceh, Jatigede di Jabar, Bajulmati dan Nipah di Jatim, Titab di Bali, Teritip di Balikpapan, Raknamo dan Tanju di NTB, sisanya akan diselesaikan hingga tahun 2023 (Kemenkeu, 2018).

Tidak hanya pengeluaran konsumsi pemerintah, sebagai negara berkembang hutang luar negeri mempunyai arti penting terhadap pertumbuhan ekonomi di Indonesia. Hutang luar negeri ditujukan untuk membiayai berbagai keperluan negara dalam rangka mendukung kegiatan ekonomi dalam negeri. Terutama kegiatan-kegiatan produktif yang demikian pada gilirannya akan mendorong pertumbuhan ekonomi (Junaedi, 2018). Adapun dalam piranti 
ekonomi Islam ada dua pendapat, ada yang membolehkan dan ada yang menolak. Zallum dalam teorinya tidak menghendaki adanya pinjaman dari negara-negara asing maupun lembaga keuangan internasional, karena dianggap pinjaman semacam ini mengandung riba dan riba hukumnya haram menurut hukum syara' (Muhajirin, 2015). Sementara Umer Chapra dalam teorinya membolehkan konsep defisit anggaran. Pembiayaan defisit APBN Umer Chapra dibagi menjadi 3 unsur penting, yaitu: penerimaan yang berasal dari pajak yang adil sesuai ketentuan Maqashid Syari'ah, kesejahteraan umum sebagai fokus utama pengeluaran, dan pembiayaan berbasis sukuk untuk menghindari hutang yang mengandung riba (Faturroyhan \& Afif, 2017).

Adapun catatan hutang luar negeri Indonesia yang disampaikan dalam publikasi BI pada triwulan IV tahun 2018 lebih rendah dibanding triwulan IV tahun 2011 yaitu 175,352 juta dolar AS. Pada triwulan IV tahun 2017 hutang luar negeri Indonesia tercatat sebesar 611,346 juta dolar AS, di mana hutang sebelumnya tahun 2016 sebesar 544,030 juta dolar AS. Sementara hutang Indonesia triwulan IV tahun 2015 meningkat dua kali lipat dari tahun 2014 yakni sebesar 476,431 juta dolar AS dan 209,709 juta dolar AS. Sedangkan pada triwulan IV tahun 2011 sebesar 199,487 juta dolar AS dan 204,520 juta dolar AS pada triwulan IV tahun 2012. Besarnya hutang luar negeri Indonesia digunakan untuk mendanai berbagai pembangunan infrastruktur pada era pemerintahan Presiden Joko Widodo.

Tidak kalah pentingnya, sektor perbankan juga dianggap mampu mendorong laju pertumbuhan ekonomi. Kapasitasnya sebagai lembaga intermediasi berdampak pada pertumbuhan sektor rill ekonomi. Saat ini telah hadir lembaga perbankan yang beroperasi sesuai ketentuan syariah, dikenal dengan sebutan perbankan syariah. Dalam transaksinya bank syariah tentu berbeda dengan bank konvensional, karena segala aktivitasnya dirangkum berdasarkan ketentuan hukum syara'. Dilihat dari data laporan perbankan syariah jumlah pembiayaan yang disalurkan dari tahun ke tahun terus mengalami peningkatan mengindikasikan meningkatnya kepercayaan masyarakat pada bank syariah (Terminanto, 2017).

Berdasarkan pada data publikasi oleh OJK jumlah penyaluran pembiayaan syariah oleh perbankan syariah di Indonesia terus mengalami peningkatan selama delapan tahun terakhir yaitu tahun 2011-2018. Hingga triwulan IV tahun 2018 diketahui jumlah pembiayaan syariah sebesar 306,996 miliar rupiah, meningkat 21,301 juta rupiah dari triwulan IV tahun 2017 sebesar 285,695 miliar rupiah, dan meningkat 2 miliar rupiah dari triwulan IV tahun 2011 sebesar 102,655 miliar rupiah.

Banyak penelitian yang membuktikan adanya hubungan antara tingkat Inflasi, Pengeluaran Konsumsi Pemerintah, Hutang Luar Negeri dan Pembiayaan Syariah terhadap Pertumbuhan Ekonomi seperti Ichvani \& Susana (Ichvani \& Susana, 2019), Junaedi (Junaedi, 2018), Larasati \& Sulasmiyati Larasati \& Sulasmiyati, 2018), Boukhatem \& Moussa (Boukhatem \& Moussa, 2018), Putra \& Sulasmiyati (Putra \& Sulasmiyati, 2018), Fitriani (Fitriani, 2018), Prastowo (Prastowo, 2018), Daniel (Daniel, 2018), Malik \& Kurnia (Malik \& Kurnia, 2017), Terminanto \& Rama (Terminanto \& Rama), Ardiansyah (Ardiansyah, 2017), Hellen dkk (Hellen dkk, 2017), Maingi (Maingi, 2017), Anggraeni (Anggraeni, 2017), MS (MS, 2017), Sijabat (Sijabat, 2017), Sari dkk (Sari dkk, 2016), Elisabeth dkk (Elisabeth dkk, 2015), Syaparuddin dkk (Syaparuddin dkk, 2015), Astuty (Astuty, 2015) dll. Namun perbedaan yang paling mendasar dengan penelitian sebelumnya adalah menjadikan teori Ekonomi Islam sebagai alat analisa terhadap pertumbuhan ekonomi. Jika penelitian sebelumnya dikupas melalui sudut pandang ilmu ekonomi konvensional, penelitian peneliti memasukkan teori keIslaman sebagai pisau bedah dalam kajian penelitian saat ini.

Berdasarkan pada paparan di atas yang didukung oleh penelitian terdahulu yang relevan, maka penelitian ini bertujuan untuk menganalisis pengaruh Inflasi, Pengeluaran Konsumsi Pemerintah, Hutang Luar Negeri dan Pembiayaan Syariah terhadap Pertumbuhan Ekonomi dengan mencoba melakukan kontruksi agama sebagai bagian dari analisisnya.

\section{Teori dan Model Penelitian Pertumbuhan Ekonomi}

Secara singkat, pertumbuhan ekonomi diartikan suatu proses kenaikan output per kapita. Pertumbuhan ekonomi berarti perkembangan kegiatan dalam perekonomian yang menyebabkan barang dan jasa yang diproduksikan dalam masyarakat meningkat (Azwar, 2016).

Menurut teori Keynes, pertumbuhan ekonomi terbentuk dari empat faktor yang secara positif mempengaruhinya. Keempat faktor tersebut adalah 
konsumsi, investasi, pengeluaran pemerintah, dan ekspor neto. Keempat faktor tersebut kembali dipengaruhi oleh faktor-faktor seperti tingkat harga, suku bunga, tingkat inflasi, money supply, nilai tukar, dan sebagainya (Khair \& Rusydi, 2016).

Di Indonesia salah satu indikator penting untuk mengukur pertumbuhan ekonomi adalah Produk Domestik Bruto (PDB). Pengukuran PDB menurut BPS menggunakan dua cara, yaitu berdasarkan harga berlaku dan harga konstan. PDB atas dasar harga berlaku dapat digunakan untuk melihat pergeseran dan struktur ekonomi, sedangkan harga konstan digunakan untuk mengetahui pertumbuhan ekonomi dari tahun ke tahun (BPS, 2019).

Muttaqin (2018) menjelaskan pertumbuhan ekonomi sebagai variabel makro ekonomi telah dirumuskan sejak dulu oleh para ahli ekonomi klasik. Menurut ekonomi Islam, pertumbuhan ekonomi bukan hanya diukur dari volume barang dan jasa yang dihasilkan pada periode tertentu. Tetapi juga perubahan yang berkesinambungan pada aspek agama, sosial dan kemasyarakatan. Tidak dikatakan ekonomi mengalami pertumbuhan apabila terjadi distorsi dan diskriminasi di dalam masyarakat. Karena dipastikan nilai-nilai tersebut melanggar ketentuan dalam ekonomi Islam (Almizan, 2016).

Dalam berbagai literatur ekonomi Islam memandang bahwa pertumbuhan ekonomi merupakan bagian dari pembangunan ekonomi. Pertumbuhan ekonomi didefinisikan dengan " $a$ suitained growth of a right kind of a right kind of output which can contribute to human welfare" atau "pertumbuhan terus-menerus dari faktor produksi secara benar yang mampu memberikan kontribusi bagi kesejahteraan manusia". Sedangkan istilah pembangunan ekonomi yang dimaksudkan dalam Islam adalah "the process of alleviating proverty and provision of ease, comfort and decency in life" atau "proses untuk mengurangi kemiskinan serta menciptakan ketentraman, kenyamanan dan susila dalam kehidupan" (Fitria, 2016).

Faktor-faktor yang mempengaruhi pertumbuhan ekonomi menurut Keynes seperti yang sudah disebutkan di atas, yaitu:

1. Inflasi

Secara harfiah inflasi dapat diartikan sebagai kenaikan tingkat harga barang dan jasa secara umum dan terus menerus selama waktu tertentu (Septiatin $\mathrm{dkk}$, 2016). Disimpulkan inflasi merupakan suatu rekasi ekonomi yang ditandai meningkatnya harga- harga secara umum dan terus menerus berkaitan dengan mekanisme pasar yang dapat dipicu oleh berbagai faktor, di antaranya tren konsumsi masyarakat yang meningkat, berlebihnya likuiditas di pasar yang memicu konsumsi atau bahkan spekulasi, dan akibat adanya ketidak lancaran distribusi barang (Marina \& K, 2016).

Adapun tingkat inflasi akan berdampak terhadap pertumbuhan ekonomi suatu negara. Teori Keynes menegaskan hubungan antara inflasi dan pertumbuhan ekonomi di mana keistimewaan teori ini adalah di dalam jangka pendek (short-run) kurva penawaran agregat (AS) adalah positif, kurva AS positif adalah harga naik dan output juga naik. Selanjutnya hubungan yang secara hipotesisnya kepada hubungan jangka panjang (long-run relationship) antara inflasi dan pertumbuhan ekonomi di mana inflasi naik akan tetapi pertumbuhan ekonomi turun (Lusbis, 2014).

Ekonom muslim menjelaskan bahwa inflasi akan berakibat buruk bagi perekonomian karena:

1) Menimbulkan gangguan terhadap fungsi uang, terutama fungsi tabungan (nilai simpan), fungsi dari pembayaran di muka, dan fungsi dari unit perhitungan. Akibat dari beban inflasi tersebut, individu harus melepaskan diri dari uang dan aset keuangan. Inflasi akan mengakibatkan terjadinya inflasi kembali, atau dengan kata lain 'self feeding inflation';

2) Akan menurunkan semangat dan sikap masyarakat terhadap menabung (turunnya Marginal Propensity to Save);

3) Meningkatkan kecendrungan untuk berbelanja barang non-primer dan barang mewah (naiknya Marginal Propensity to Consume);

4) Meningkatka investasi non-produktif yang bersifat penumpukkan kekayaan (hoarding) seperti: tanah, bangunan, logam mulia, mata uang asing dengan mengorbankan investasi ke arah produktif seperti: pertanian, industrial, perdagangan, transportasi, dan lainnya (Adiwarman, 2014).

Al-Maqrizi menjelaskan bahwa inflasi terjadi karena dua faktor, yaitu faktor alamiah (natural inflation) dan inflasi karena kesalahan manusia (human error inflation). Inflasi alamiah disebabkan karena bencana alam yang akan menyebabkan bahan makanan dan hasil bumi mengalami gagal panen, sehingga supply menurun dan menimbulkan kelangkaan. Kelangkaan inilah yang memicu 
terjadinya kenaikan harga. Sementra inflasi karena kesalahan manusia di antaranya disebabkan karena tindakan korupsi dan administrasi yang buruk, pajak yang berlebih, dan pencetakan uang dengan maksud menarik keuntungan yang berlebihan.

Penelitian yang dilakukan oleh Ardiansyah yang menemukan bahwa inflasi baik dalam jangka pendek maupun jangka panjang berkorelasi negatif terhadap pertumbuhan ekonomi (Ardiansyah, 2017). Penelitian lain yang dilakukan di Jambi juga menemukan inflasi berpengaruh negatif terhadap pertumbuhan ekonomi (Daniel, 2018). Larasati \& Sulasmiyati yang melakukan studi kasus di Indonesia, Malaysia, Singapuram, dan Thailand juga menemukan inflasi berpengaruh negatif dan signifikan terhadap PDB (Larasati \& Sulasmiyati, 2018). Selanjutnya oleh Nurhidayati menemukan inflasi berkorelasi negatif terhadap pertumbuhan ekonomi (Nurhidayati, 2015). Berdasarkan deskripsi di atas hipotesis yang dikemukakan adalah sbb:

H1 : Inflasi memiliki pengaruh negatif terhadap Pertumbuhan Ekonomi.

\section{Pengeluaran Konsumsi Pemerintah}

Pengeluaran pemerintah merupakamsalah satu intervensi pemerintah terhadap perekonomian yang dianggap paling efektif (Danawati, 2016). Sukirno (2009) menjelaskan, pengeluaran pemerintah (government expenditure) adalah bagian dari kebijakan fiskal, yaitu suatu tindakan pemerintah untuk mengatur jalannya perekonomian dengan cara menentukan besarnya penerimaan dan pengeluaran pemerintah setiap tahunnya, yang tercermin dalam dokumen APBN untuk nasional dan APBD untuk daerah atau regional (Handayani, 2015).

BPS menjelaskan bahwa Pengeluaran Konsumsi Pemerintah adalah nilai seluruh jenis output Pemerintah dikurangi nilai output untuk pembentukan modal sendiri dikurangi nilai penjualan barang/jasa (baik yang harganya signifikan dan tidak signifikan secara ekonomi) ditambah nilai barang/jasa yang dibeli dari produsen pasar untuk diberikan pada RT secara gratis yang tidak signifikan secara ekonomi (social transfer in kind-purchased market production).

Menurut MS (2017) Pengeluaran Konsumsi Pemerintah merupakan salah satu variabel makro ekonomi yang berpengaruh terhadap pertumbuhan ekonomi. Jika pengeluaran konsumsi pemerintah bertambah maka berpengaruh positif terhadap pertumbuhan ekonomi. Kontribusi pengeluaran produktif akan mendorong pergerakan ekonomi dan pertumbuhan ekonomi akan meningkat.

Di dunia Islam, pengeluaran pemerintah memegang posisi paling utama karena menyangkut pemenuhan kebutuhan setiap individu di dalamnya baik kebutuhan primer, sekunder maupun tersier (alhajat al-kamaliyyah). Pemenuhan kebutuhan ini menurut para fuqaha hukumnya adalah fardhu kifayah, sehingga konsentrasi ekonomi Islam adalah distribusi ekonomi yang merata agar setiap orang mendapatkan standar hidup yang manusiawi, terhormat, dan sesuai dengan martabat manusia sebagai khalifah Allah. (Rahmawati, 2008).

Secara sistematis belanja pemerintah pada masa Rasulullah SAW diperuntukkan untuk membiayai berbagai kebutuhan negara yang sudah dibagi antara kebutuhan primer dan sekunder, di antara biaya pertahanan, pembayaran gaji, pembayaran hutang negara, upah sukarelawan, bantuan untuk musafir, bahkan zakat dikategorikan menjadi kebutuhan primer. Sementara biaya pendidikan dan biaya lainlainnya di luar itu masuk dalam kelompok kebutuhan sekunder.

Banyak penelitian yang membuktikan relasi antara pengeluaran konsumsi pemerintah dan pertumbuhan ekonomi, di antaranya penelitian oleh Ichvani \& Susana yang meneliti pertumbuhan ekonomi di ASEAN 5 mengatakan bahwa variabel pengeluaran pemerintah berpengaruh signifikan terhadap pertumbuhan ekonomi di negara ASEAN (Ichvani \& Susana, 2019). MS yang melakukan penelitian di Jambi juga mengungkapkan pengeluaran pemerintah berpengaruh secara signifikan dan positif terhadap pertumbuhan ekonomi Provinsi Jambi (MS, 2017). Penelitian oleh Anggraeni menemukan adanya pengaruh positif dan signifikan baik dalam jangka panjang maupun jangka pendek ECT pengeluaran pemerintah di sektor pendidikan, kesehatan, dan pertanian secara parsial dan simultan terhadap pertumbuhan ekonomi di Indonesia (Anggraeni, 2017). Sijabat menegaskan dalam penelitiannya bahwa berbagai jenis pengeluaran pemerintah dalam bidang produktif menyebabkan peningkatan terhadap pertumbuhan ekonomi (Sijabat, 2017). Begitupun diugkapkan oleh Abdullah \& Rusdarti yang menemukan fakta pengeluaran pemerintah berdampak positif terhadap pertumbuhan ekonomi Indonesia, Malaysia, dan Singapura (Abdullah \& 
Rusdarti, 2017). Berdasarkan deskripsi di atas hipotesis yang dikemukakan adalah sbb:

H2 : Pengeluaran Konsumsi Pemerintah memiliki pengaruh positif terhadap Pertumbuhan Ekonomi.

\section{Hutang Luar Negeri}

Kamus Besar Bahasa Indonesia mendefinisikan pinjaman sebagai utang yang dipinjamkan dari pihak lain dengan kewajiban membayar kembali (Junaedi, 2018). Menurut SKB Menteri Keuangan dan Kepala Bappenas (No.185/KMK.03/1995 dan Nomor KEP.031/KET/5/1995), Pinjaman Luar Negeri adalah penerimaan negara baik dalam bentuk devisa, dan atau devisa yang dirupiahkan maupun dalam bentuk barang dan atau jasa yang diperoleh dari pemberian pinjaman luar negeri yang harus dibayar kembali dengan persyaratan tertentu (Syaparuddin dkk, 2015).

Syaparuddin dkk (2015) menambahkan jika dilihat dari jangka waktunya, hutang luar negeri dapat dibagi menjadi: (1) hutang jangka pendek, (2) hutang jangka menengah, dan (3) hutang jangka panjang. Hutang jangka pendek adalah hutang dengan jangka waktu jatuh tempo (maturity) satu tahun. Hutang jangka menengah merupakan hutang dengan jangka waktu jatuh tempo 5-15 tahun. Sedangkan, hutang jangka panjang adalah hutang yang jangka waktu jatuh tempo lebih dari 15 tahun. Hutang merupakan bagian dari kebijakan fiskal (APBN) yang menjadi bagian dari kebijakan pengelolaan ekonomi secara keseluruhan. Hutang terutama merupakan konsekwensi dari postur APBN (yang mengalami defisit), di mana pendapatan negara lebih kecil dari pada belanja negara.

Sementara Muhajirin (2015) mengungkapkan bahwa di dalam Islam terdapat dua pandangan terkait hutang negara, yaitu kelompok yang setuju dengan anggaran berimbang dan kelompok yang membolehkan anggaran defisit. Kelompok pertama berpendapat bahwa pembiayaan tidak boleh defisit (pengeluaran lebih besar dari pendapatan), dapat menyebabkan pemerintah berutang dengan konsekuensi membayar bunga, dan mendekati riba. Pengeluaran yang bertambah ini juga dapat menyebabkan pemborosan. Sedangkan kelompok kedua berpendapat sudah tidak waktunya lagi negaranegara Islam mempertahankan konsep anggaran berimbang yang akan membuat pertumbuhan ekonomi melambat dan terhambatnya ekplorasi sumber daya alam karena ketiadaan modal. Negara
Islam yang kaya sumber daya alam, namun kurang modal harus meminjam modal ke negara lain untuk mengeplorasi sumber daya alamnya, atau dengan memungut pajak.

Tabel 1. Pandangan Islam Terhadap Hutang Luar Negeri

\begin{tabular}{|c|c|}
\hline $\begin{array}{c}\text { Pro Hutang (External } \\
\text { Financing) }\end{array}$ & $\begin{array}{c}\text { Kontra Hutang } \\
\text { (External } \\
\text { Financing) }\end{array}$ \\
\hline \begin{tabular}{|lr} 
Boleh sepanjang & bentuk \\
dan mekanisme & sesuai \\
dengan syariat. & \\
\end{tabular} & $\begin{array}{l}\text { Tidak boleh menutup } \\
\text { budget deficit dengan } \\
\text { hutang luar negeri. }\end{array}$ \\
\hline $\begin{array}{l}\text { Latar belakang: } \\
\text { Konsep dan fakta historis } \\
\text { bahwa kerjasama dengan } \\
\text { pihak lain dalam satu usaha } \\
\text { diperbolehkan, bahkan } \\
\text { dianjurkan. } \\
\text { Bentuk kerjasama dalam } \\
\text { Islam seperti murabahah, } \\
\text { mudharabah, musyarakah } \\
\text { dapat dikembangkan } \\
\text { sebagai external financing } \\
\text { dan juga bentuk-bentuk ini } \\
\text { lebih ke arah creating } \\
\text { equity. }\end{array}$ & $\begin{array}{l}\text { Latar belakang: } \\
\text { Tendensinya ke arah } \\
\text { faktual dan preventif, } \\
\text { di mana keterlibatan } \\
\text { negera-negara Islam } \\
\text { dalam hutang luar } \\
\text { negeri pasti akan } \\
\text { bersentuhan dengan } \\
\text { riba. }\end{array}$ \\
\hline
\end{tabular}

Sumber: Faishol Luthfi, 2018

Teori di atas telah dibuktikan oleh beberapa penelitian, yaitu Junaedi yang menemukan bahwa hutang luar negeri memiliki korelasi terhadap pertumbuhan ekonomi nasional (Junaedi, 2018). Kemudian Malik \& Kurnia juga mengungkapkan hutang luar negeri memberi dampak positif dan signifikan terhadap pertumbuhan ekonomi (Malik \& Kurnia, 2017). Pun diperkuat oleh Rahman dkk (Rahman dkk, 2017) dan Khair \& Rusydi (Khair \& Rusydi, 2016) menemukan hasil yang sama. Sementara Syaparuddin dkk dalam penelitiannya dengan menggunakan metode regresi data panel, hasilnya menunjukkan peningkatan hutang luar negeri berakibat pada perlambatan atau penurunan pertumbuhan ekonomi selama periode 1990-2013 terjadi Indonesia, Malaysia, dan Vietnam serta Thailand. Sedangkan yang dapat mendorong peningkatan pertumbuhan ekonomi terjadi di Fhilipina dan Myanmar (Syaparuddin dkk, 2015). ). Berdasarkan deskripsi di atas hipotesis yang dikemukakan adalah sbb:

H3 : Hutang Luar Negeri memiliki pengaruh positif terhadap Pertumbuhan Ekonomi. 


\section{Pembiayaan Syariah}

Dalam UU Nomor 10 Tahun 1998 disebutkan bahwa pembiayaan berdasarkan prinsip syariah adalah "penyediaan uang atau tagihan yang dipersamakan dengan itu berdasarkan persetujuan atau kesepakatan antara bank dengan pihak lain yang mewajibkan pihak yang dibiayai untuk mengembalikan uang atau tagihan tersebut setelah jangka waktu tertentu dengan imbalan atau bagi hasil" (Ilyas, 2015).

Dalam pelaksanaan pembiayaan, bank syariah harus memenuhi dua aspek yaitu Aspek Syar'i dan Aspek Ekonomi. Aspek Syar'i berarti dalam setiap realisasi pembiayaan kepada nasabah, bank syariah harus tetap berpedoman pada syariat Islam (antara lain tidak mengandung unsur maisyir, gharar dan riba serta bidang usahanya harus halal). Sedangkan Aspek Ekonomi, di samping mempertimbangkan halhal syariah, bank syariah tetap mempertimbangkan perolehan keuntungan baik bagi bank syariah maupun bagi nasabah bank syariah (Astuty, 2015).

Dalam operasionalnya bank syariah menggunakan tiga model akad pembiayaan yaitu:

a. Pembiayaan dengan pola bagi hasil terdiri dari pembiayaan mudharabah dan musyarakah.

b. Pembiayaan dengan pola jual beli terdiri dari murabahah, istishna' dan salam.

c. Pembiayaan dengan pola ujroh terdiri dari ijarah dan ijarah al-muntahiya bit-tamlik.

Sektor keuangan mempunyai kedudukan penting dalam mendorong pertumbuhan ekonomi. Hal ini dikarenakan fungsi perbankan yang bertindak sebagai manajer investasi dan investor dapat mendukung pengembangan sektor rill, baik dalam rangka meningkatkan iklim usaha maupun iklim investasi serta juga penciptaan lapangan kerja. Fungsi perbankan dalam menghimpun dan memobilisasi dana-dana masyarakat atau perusahaan kemudian disalurkan pada usaha-usaha produktif berpengaruh positif terhadap peningkatan pertumbuhan ekonomi nasional (Deti dkk, 2017).

Adapun teori di atas diperkuat oleh banyak penelitian yang telah dilakukan, di antaranya penelitian oleh Prastowo yang melakukan studi empiris di 13 negara dan menyimpulkan bahwa variabel pembiayaan syariah memiliki pengaruh positif terhadap pertumbuhan ekonomi (Prastowo, 2018). Salah satu penelitian oleh Boukhatem \& Moussa yang secara empiris untuk menilai pengaruh pinjaman perbankan syariah terhadap pertumbuhan ekonomi 13 negara di kawasan MENA selama periode 2000-2004 dan ditemukan hasil bahwa pemberian pinjaman oleh perbankan syariah merangsang peningkatan pada pertumbuhan ekonomi di negara-negara MENA (Boukhatem \& Moussa, 2018). Kemudian Terminanto \& Rama yang melakukan studi kasus pada provinsi di Indonesia juga menjelaskan pembiayaan pada bank syariah berpengaruh positif terhadap pertumbuhan ekonomi di Indonesia (Terminanto \& Rama, 2017). Dampak positif pembiayaan pada bank syariah terhadap pertumbuhan ekonomi dijelaskan juga dalam penelitian Astuty (Astuty, 2015). Berdasarkan deskripsi di atas hipotesis yang dikemukakan adalah sbb:

H4 : Pembiayaan Syariah memiliki pengaruh positif terhadap Pertumbuhan Ekonomi.

Berdasarkan deskripsi di atas, maka model penelitian ini adalah sebagai berikut:

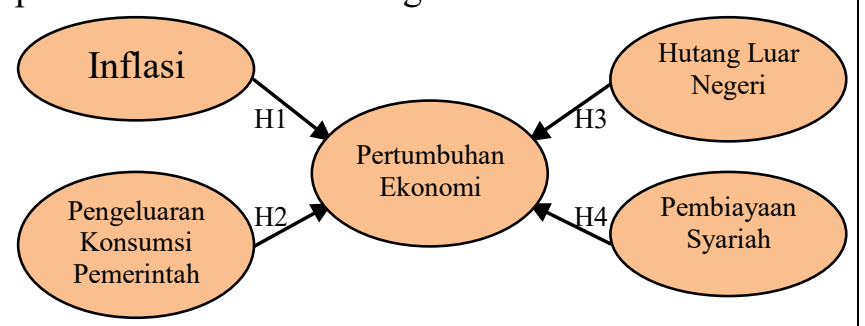

Gambar 2. Model Penelitian

\section{METODOLOGI PENELITIAN}

Dalam penelitian ini, paradigma yang digunakan adalah paradigma Profetik, yaitu proses pengilmuan ayat-ayat al-Qur'an. Kaitannya dengan penjelasan tersebut dalam penelitian ini, yaitu mencoba mengumpulkan data ekonomi yang diperoleh dari Badan Pusat Statistik, Bank Indonesia, Otoritas Jasa Keuangan dan publikasi lainnya yang kemudian diuji secara statistik menggunakan alat uji eviews 10 yang kemudian di bedah dalam bingkai keIslaman, yakni memasukkan sub-sub keIslaman dalam analisisnya dalam rangka penselarasan keilmuan umum dan teori Islam seperti yang terkandung dalam nilai-nilai profetik.

Adapun metode analisis data yang digunakan dalam penelitian ini adalah Error Correction Model (ECM), yaitu bertujuan untuk mengestimasi pengaruh jangka panjang dan pengaruh jangka pendek variabel inflasi, pengeluaran konsumsi pemerintah, hutang luar negeri dan pembiayaan syariah terhadap pertumbuhan ekonomi di Indonesia. Model tersebut selengkapnya disajikan, sebagai berikut: 
1. Bentuk persamaan ECM untuk estimasi jangka panjang:

$\mathrm{PE}_{\mathrm{t}}=\alpha_{0}+\alpha_{1} \mathrm{INF}_{\mathrm{t}}+\alpha_{2} \mathrm{PKP}_{\mathrm{t}}+\alpha_{3} \mathrm{HLN}_{\mathrm{t}}+\alpha_{4} \mathrm{PS}_{\mathrm{t}}$

Keterangan:

$\mathrm{PE}_{\mathrm{t}} \quad$ : Pertumbuhan Ekonomi periode $\mathrm{t}$

$\mathrm{INF}_{\mathrm{t}}$ : Inflasi periode $\mathrm{t}$

$\mathrm{PKP}_{\mathrm{t}}$ : Pengeluaran Konsumsi Pemerintah periode $\mathrm{t}$

$\mathrm{HLN}_{\mathrm{t}}$ : Hutang Luar Negeri periode $\mathrm{t}$

$\mathrm{PS}_{\mathrm{t}} \quad$ : Pembiayaan Syariah periode $\mathrm{t}$

$\alpha_{0} \alpha_{1} \alpha_{2} \alpha_{3} \alpha_{4}$ : Koefisien Jangka Panjang

2. Bentuk persamaan ECM untuk estimasi jangka pendek adalah sebagai berikut:

$\mathrm{DPE}_{\mathrm{t}}=\alpha_{1} \mathrm{DINF}_{\mathrm{t}}+\alpha_{2} \mathrm{DPKP}_{\mathrm{t}}+\alpha_{3} \mathrm{DHLN}_{\mathrm{t}}+\alpha_{4} \mathrm{DPS}_{\mathrm{t}}$ RES(-1) .... (2)

Keterangan:

$\mathrm{DPE}_{\mathrm{t}}$ : Perubahan Pertumbuhan ekonomi Periode $\mathrm{t}$

DINF $_{\mathrm{t}}$ : Perubahan Inflasi Periode $\mathrm{t}$

DPKP $_{t}$ :Perubahan Pengeluaran Konsumsi Pemerintah Periode $t$

DHLN $_{t}$ :Perubahan Hutang Luar Negeri Periode $t$ DPS $_{\mathrm{t}}$ : Perubahan Pembiayaan Syariah Periode $\mathrm{t}$ $\alpha_{0} \alpha_{1} \alpha_{2} \alpha_{3} \alpha_{4}$ : Koefisien Jangka Pendek

Kriteria pengujian Error Correction Model (ECM):

a. $\mathrm{H}_{0}$ : Ada pengaruh

Ha : Tidak ada pengaruh

b. Tingkat signifikansi $95 \%$ atau $\alpha=5 \%$

c. Statistik uji : Error Correction Model (ECM)

d. Daerah kritis : $\mathrm{H}_{0}$ ditolak jika nilai Probabilitas $>$ Critical Value $(\alpha=5 \%)$

e. Kesimpulan: $\mathrm{H}_{0}$ diterima karena nilai Probabilitas $<$ Critical Value $(\alpha=5 \%)$

Untuk terpenuhinya model ECM di atas, maka harus lolos dalam uji pra syarat penelitian, antara lain:

a. Uji Akar Unit (Unit Root Test)

Uji akar unit dipakai untuk menguji suatu data runtut waktu stasioner atau tidak. Apabila suatu data ditemukan tidak stasioner maka dikatakan data tersebut mengalami permasalahan akar unit (unit root problem).

Untuk menentukan apakah data stasioner atau tidak, bisa dilakukan menggunakan uji akar unit dengan metode Dickey-Fuller (Dickey-Fuller test) yaitu salah satu cara yang digunakan untuk mendeteksi apakah data stasioner pada level atau diffrence. Data dikatakan stasioner apabila nilai probabilitas pada Dickey-Fuller test lebih kecil dari
0,05 . Apabila nilai probabilitas lebih besar dari 0,05 maka dapat disimpulkan bahwa data tidak stasioner.

b. Uji Kointegrasi

Pengujian kontegrasi antar variabel bertujuan untuk melihat hubungan jangka panjang antara variabel independen dengan variabel dependen. Untuk mengetahui adanya kointegrasi ini maka data diuji menggunakan metode Engle-Granger dan langkah uji Johansen. Namun dalam penelitian ini hanya menggunakan uji Engle-Granger.

Berikut persamaan kointegrasi dalam penelitian ini, yaitu:

$\mathrm{PE}_{\mathrm{t}}=\alpha_{0}+\alpha_{1} \Delta \mathrm{INF}_{\mathrm{t}}+\alpha_{2} \mathrm{PKP}_{\mathrm{t}}+\alpha_{3} \mathrm{HLN}_{\mathrm{t}}+\alpha_{4} \mathrm{PS}_{\mathrm{t}}+e_{\mathrm{t}}(1)$

Keterangan:

$\mathrm{PE}_{\mathrm{t}} \quad$ : Pertumbuhan Ekonomi Periode $\mathrm{t}$

$\mathrm{INF}_{\mathrm{t}} \quad$ : Inflasi Periode $\mathrm{t}$

$\mathrm{PKP}_{\mathrm{t}}$ : Pengeluaran Konsumsi Pemerintah periode $\mathrm{t}$

$\mathrm{HLN}_{\mathrm{t}} \quad$ : Hutang Luar Negeri Periode $\mathrm{t}$

$\mathrm{PS}_{\mathrm{t}} \quad$ : Pembiayaan Syariah Periode $\mathrm{t}$

$\alpha_{0} \alpha_{1} \alpha_{2} \alpha_{3} \alpha_{4}$ : Koefisien Kointegrasi

Kriteria uji kointegrasi data:

1) $\mathrm{H}_{0}:$ Ada kointegrasi

Ha : Tidak ada kointegrasi

2) Tingkat signifikansi $95 \%$ atau $\alpha=5 \%$

3) Statistik uji : nilai ADF

4) Daerah kritis : $\mathrm{H}_{0}$ ditolak jika nilai $\mathrm{ADF}>$ Critical Value $(\alpha=5 \%)$

5) Kesimpulan: $\mathrm{H}_{0}$ diterima karena nilai $\mathrm{ADF}<$ Critical Value $(\alpha=5 \%)$

c. Uji Asumsi Klasik

Uji ini dilakukan untuk menemukan ada tidaknya penyimpangan asumsi klasik pada data penelitian. Ada empat uji yang digunakan, antara lain: uji normalitas, uji heteroskedastisitas, uji autokorelasi, dan uji multikolinearitas.

\section{HASIL PENELITIAN}

Penelitian peneliti menggunakan data sekunder yang terdiri dari Pertumbuhan Ekonomi, Inflasi, Pengeluaran Konsumsi Pemerintah, Hutang Luar Negeri dan Pembiayaan Syariah di Indonesia yang diambil dari publikasi Badan Pusat Statistik (BPS), Bank Indonesia (BI) dan Otoritas Jasa Keuangan (OJK) selama kurun waktu 8 tahun yakni tahun 20112018. Berikut di bawah ini adalah hasil uji statistik menggunakan program Eviews 10: 
Hasil Uji Prasyarat Penelitian

1. Uji Akar Unit (Unit Root Test)

Tabel 2. Hasil Uji Akar-akar Unit dengan Augment Dickey-Fuller test pada Level

\begin{tabular}{|l|c|}
\hline \multicolumn{1}{|c|}{ ADF Statistik } & \multicolumn{1}{|c|}{ Keterangan } \\
\hline Pertumbuhan Ekonomi \\
\hline-1.662202 & Tidak Stasioner \\
\hline Inflasi & Tidak Stasioner \\
\hline-8.159948 & Tidak Stasioner \\
\hline Pengeluaran Konsumsi Pemerintah \\
\hline-0.739076 & Tidak Stasioner \\
\hline Hutang Luar Negeri \\
\hline-1.519218 & Tidak Stasioner \\
\hline Pembiayaan Syariah & \\
\hline-0.958748 & \\
\hline
\end{tabular}

Sumber: Data diolah, Eviews 10, 2019

Berdasarkan table 2, didapatkan hasil variabel penelitian tidak stasioner tingkat level. Hanya variabel Inflasi yang stasioner. Sedangkan variabel Pertumbuhan Ekonomi, Pengeluaran Konsumsi Pemerintah, Hutang Luar Negeri dan Pembiayaan Syariah tidak stasioner. Untuk itu, agar semua data stasioner pada derajat sama maka dilakukan proses diferensiasi, yaitu:

Tabel 3. Hasil Uji Akar-akar Unit dengan Augmen Dickey-Fuller test pada Firs Difference

\begin{tabular}{|l|c|}
\hline \multicolumn{1}{|c|}{ ADF Statistik } & Keterangan \\
\hline Pertumbuhan Ekonomi \\
\hline-6.866702 & Stasioner \\
\hline Inflasi & Stasioner \\
\hline-5.047505 & Stasioner \\
\hline Pengeluaran Konsumsi Pemerintah \\
\hline-20.71663 & \\
\hline Hutang Luar Negeri & Stasioner \\
\hline-5.276492 & \\
\hline Pembiayaan Syariah & Stasioner \\
\hline-5.044749 & \\
\hline
\end{tabular}

Sumber: Data diolah, Eviews 10, 2019

Hasil uji akar-akar unit Augmented DickeyFuller (ADF) test pada tingkat first difference menunjukkan bahwa semua data telah stasioner pada derajat yang sama yaitu first difference.

1. Uji Kointegrasi

Tabel 4. Hasil Uji Kointegrasi

\begin{tabular}{|c|c|c|c|}
\hline & t-Static & Prob.* \\
\hline \multicolumn{2}{|c|}{$\begin{array}{l}\text { Augmented Dickey- } \\
\text { Fuller test statistic }\end{array}$} & -4.059875 & 0.0046 \\
\hline \multirow{3}{*}{$\begin{array}{l}\text { Test } \\
\text { critical } \\
\text { values }\end{array}$} & $1 \%$ level & -3.724070 & \\
\hline & $5 \%$ level & -2986225 & \\
\hline & $10 \%$ level & -2.632604 & \\
\hline
\end{tabular}

Sumber: Data diolah, Eviews 10, 2019
Berdasarkan uji ADF pada tabel 4 di atas diketahui bahwa persamaan jangka panjang telah signifikan pada tingkat level. Hal ini dibuktikan nilai ADF statistic $>$ dari $1 \%, 5 \%$ maupun $10 \%$ atau dilihat dari probabilitasnya adalah 0,0046 atau lebih kecil dari 0,05 .

2. Uji Asumsi Klasik

a. Uji Normalitas

Tabel 5. Hasil Uji Normalitas

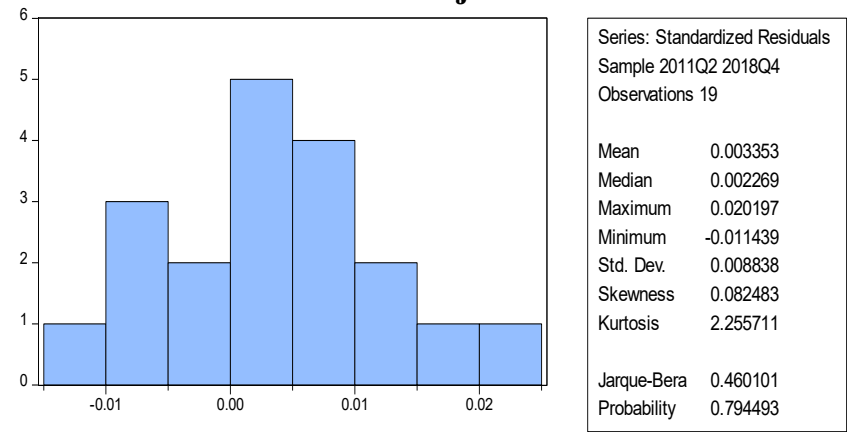

Sumber: Data diolah, Eviews 10, 2019

Berdasarkan pada tabel 5 di atas dapat dilihat bahwa nilai Jarque-Bera sebesar 0,460101 dan nilai probalitiasnya sebesar 0,794493 , artinya lebih besar dari 0,05 $(0,460101>0,05$ dan 0,794493 >0,05). Disimpulkan data telah terdistribusi normal secara statistik.

b. Uji Heteroskedastisitas

Tabel 6. Hasil Uji Heteroskedastisitas

\begin{tabular}{|l|l|l|l|}
\hline \multicolumn{4}{|l|}{ Heteroskedasticity } \\
\hline F-statistic & 1.285579 & Prob. F(5,13) & $\mathbf{0 . 3 2 8 1}$ \\
\hline $\begin{array}{l}\text { Obs*R- } \\
\text { squared }\end{array}$ & 6.286323 & $\begin{array}{l}\text { Prob. Chi- } \\
\text { Square(5) }\end{array}$ & 0.2793 \\
\hline $\begin{array}{l}\text { Scaled } \\
\text { explained } \\
\text { SS }\end{array}$ & 4.067510 & $\begin{array}{l}\text { Prob. Chi- } \\
\text { Square(5) }\end{array}$ & 0.5397 \\
\hline
\end{tabular}

Sumber: Data diolah, Eviews 10, 2019

Berdasarkan pada tabel 6 di atas diketahui nilai Prob. F hitung sebesar 0,3281 yakni lebih besar dari $0,05(0,3281>0,05)$. Sehingga disimpulkan $\mathrm{H}_{0}$ diterima yang artinya tidak terjadi heteroskedastisitas. c. Uji Autokorelasi

Tabel 7. Hasil Uji Autokorelasi

\begin{tabular}{|l|l|l|l|}
\hline \multicolumn{4}{|c|}{ Breusch-Godfrey Serial Correlation LM Test: } \\
\hline F-statistic & 510.9943 & Prob. F(2,11) & $\mathbf{0 . 0 0 0 0}$ \\
\hline $\begin{array}{l}\text { Obs*R- } \\
\text { squared }\end{array}$ & 18.79767 & $\begin{array}{l}\text { Prob. Chi- } \\
\text { Square(2) }\end{array}$ & 0.0001 \\
\hline
\end{tabular}

Sumber: Data diolah, Eviews 10, 2019

Berdasarkan hasil uji Autokorelasi di atas menggunakan uji LM (Lagrange Multiplier) diketahui nilai probabilitas $\mathrm{F}$ hitung sebesar 0,0000 , artinya lebih kecil dari $0,05(0,0000<0,05)$. Karena 
nilai probabilitas lebih kecil dari 0,05 maka $\mathrm{H}_{0}$ ditolak, sehingga disimpulkan data linier terjadi autokorelasi. Oleh karena terjadi autokolerasi pada data statistik, maka dilakukan penyembuhan dengan metode Cochranee-Orcut $(\operatorname{ar}(1)$ dan $\operatorname{ar}(2))$, yaitu hasilnya sebagai berikut:

Tabel 8. Hasil Uji Autokorelasi Metode Cocharance-Orcut

\begin{tabular}{|c|c|c|c|}
\hline R-squared & 1.000000 & $\begin{array}{l}\text { Mean } \\
\text { dependent var }\end{array}$ & $\begin{array}{l}5.46406 \\
3\end{array}$ \\
\hline $\begin{array}{l}\text { Adjusted } \\
\text { R-squared }\end{array}$ & 1.000000 & $\begin{array}{l}\text { S.D. } \\
\text { dependent var }\end{array}$ & $\begin{array}{l}0.61896 \\
8\end{array}$ \\
\hline $\begin{array}{l}\text { S.E. of } \\
\text { regression }\end{array}$ & $5.82 \mathrm{E}-16$ & $\begin{array}{l}\text { Sum squared } \\
\text { resid }\end{array}$ & $\begin{array}{l}7.80 \mathrm{E}- \\
30\end{array}$ \\
\hline F-statistic & $4.38 \mathrm{E}+30$ & $\begin{array}{l}\text { Durbin- } \\
\text { Watson stat }\end{array}$ & $\begin{array}{l}2.00337 \\
8\end{array}$ \\
\hline $\begin{array}{l}\text { Prob(F- } \\
\text { statistic) }\end{array}$ & 0.000000 & & \\
\hline $\begin{array}{l}\text { Akaike info } \\
\text { criterion }\end{array}$ & 67.25406 & & \\
\hline $\begin{array}{l}\text { Hannan- } \\
\text { Quinn criter. }\end{array}$ & & & \\
\hline
\end{tabular}

Sumber: Data diolah, Eviews 10, 2019

Ada tidaknya autokorelasi dilihat dari nilai uji Durbin-Waston, yaitu diperoleh nilai DW hitung sebesar 2,003378, nilai DU sebesar 1,7323 dan nilai 4-DU sebesar 6,9292. Adapun ketentuan pengujian autokorelasi pada Durbin-Waston yaitu: DU < DW < 4-DU, maka disimpulkan 1,7323<2,003378< 6,9292. Artinya posisinya berada pada daerah tidak ada autokorelasi. Sehingga dikatakan data linier bebas dari adanya autokorelasi.

d. Uji Multikolinearitas

Tabel 9. Hasil Uji Multikolinearitas

\begin{tabular}{|c|c|c|c|c|}
\hline & Inflasi & $\begin{array}{c}\text { Pengeluaran } \\
\text { Konsumsi } \\
\text { Pemerintah }\end{array}$ & $\begin{array}{c}\text { Hutang } \\
\text { Luar } \\
\text { Negeri }\end{array}$ & $\begin{array}{c}\text { Pembiayaa } \\
\text { n Syariah }\end{array}$ \\
\hline Inflasi & 1.000000 & 0.508884 & -0.024970 & 0.069650 \\
\hline $\begin{array}{c}\text { Pengeluara } \\
\text { n Konsumsi } \\
\text { Pemerintah }\end{array}$ & 0.508884 & 1.000000 & 0.315708 & 0.503552 \\
\hline $\begin{array}{c}\text { Hutang } \\
\text { Luar } \\
\text { Negeri }\end{array}$ & -0.024970 & 0.315708 & 1.000000 & 0.468083 \\
\hline $\begin{array}{c}\text { Pembiayaa } \\
\text { n Syariah }\end{array}$ & 0.069650 & 0.503552 & 0.468083 & 1.000000 \\
\hline
\end{tabular}

Sumber: Data diolah, Eviews 10, 2019

Berdasarkan pada tabel 9 di atas diketahui nilai matrik korelasi (correlation matrix) multikolinearitas penelitian kurang dari 0,85 . Karena nilai matrik korelasi dari keempat variabel independen tidak ada yang lebih dari 0,85 , dengan demikian variabel di atas telah terbebas dari adanya multikolinearitas.

\section{Hasil Uji Hipotesis}

1. Estimasi Model ECM Jangka Panjang

Tabel 10. Hasil Estimasi Model ECM Jangka Panjang

\begin{tabular}{|c|c|c|c|}
\hline Variable & Coefficient & Std. Error & t-Statistic \\
\hline PKP & 0.000307 & 0.000348 & 0.882926 \\
\hline HLN & -0.001108 & 0.000428 & -2.590959 \\
\hline INF & -0.124837 & 0.148738 & -0.839307 \\
\hline PS & -0.006860 & 0.001201 & -5.713453 \\
\hline C & 7.152866 & 0.219908 & 32.52660 \\
\hline R-squared & 0.729081 & $\begin{array}{c}\text { Mean } \\
\text { dependent var }\end{array}$ & 5.464063 \\
\hline $\begin{array}{c}\text { Adjusted R- } \\
\text { squared }\end{array}$ & 0.688945 & $\begin{array}{c}\text { S.D. } \\
\text { dependent var }\end{array}$ & 0.618968 \\
\hline $\begin{array}{c}\text { Prob(F- } \\
\text { statistic) }\end{array}$ & 0.000000 & & \\
\hline
\end{tabular}

Sumber: Data diolah, Eviews 10, 2019

Berdasarkan tabel 10 maka diperoleh model ECM jangka panjang sebagai berikut:

$$
\begin{aligned}
\mathrm{PE}_{\mathrm{t}}= & \alpha_{0}+\alpha_{1} \mathrm{INF}_{\mathrm{t}}+\alpha_{2} \mathrm{PKP}_{\mathrm{t}}+\alpha_{3} \mathrm{HLN}_{\mathrm{t}}+\alpha_{4} \mathrm{PS}_{\mathrm{t}} \\
= & 7,152866 \_\mathrm{C}-0,001108 \text { INF }+ \\
& 0,000307 \text { PKP }-0,001108 \_\mathrm{HLN}- \\
& 0,006860 \text { PS }
\end{aligned}
$$

Pengaruh inflasi ke pertumbuhan ekonomi (probabilitas $=0,4087)>(\alpha=0,05)$ maka $\mathrm{H}_{0}$ ditolak yang berarti data tidak signifikan. Jika dilihat dari nilai (koefisien $=-0,124837$ ), karena nilai koefisien bertanda negatif artinya inflasi berpengaruh negatif terhadap prtumbuhan ekonomi. Sehingga disimpulkan hipotesis 1 diterima dan inflasi bisa digunakan sebagai model jangka panjang. Pengeluaran konsumsi pemerintah tidak berpengaruh terhadap pertumbuhan ekonomi yang ditunjukkan dengan nilai (probabilitas $=0,3851)>(\alpha=0,05)$. Dengan demikian hipotesis 2 yang berbunyi "pengeluaran konsumsi pemerintah memiliki pengaruh positif terhadap pertumbuhan ekonomi" tidak didukung oleh data empiris. Hutang Luar negeri berdasarkan hasil estimasi jangka panjang mempunyai nilai (probabilitas $=0,0152)<(\alpha=0,05)$ maka $\mathrm{H}_{0}$ diterima dan data dinyatakan signifikan. Namun karena nilai (koefisien $=-0,001108$ ) bertanda negatif artinya hutang luar negeri memberi pengaruh negatif ke pertumbuhan ekonomi. Oleh karena itu, hipotesis 3 tidak bisa dijadikan model dalam penelitian ini. Pembiayaan syariah memiliki data yang signifikan (probabilitas $=0,0000)<(\alpha=0,05)$, akan tetapi tidak berpengaruh terhadap pertumbuhan ekonomi, hal ini terbukti dari (koefisien = 0,006860). Dengan demikian hipotesis 4 tidak diterima sebab tidak didukung data empiris.

2. Estimasi Model ECM Jangka Pendek 
Jurnal Ilmiah Ekonomi Islam, 6(02), 2020, 233

Tabel 11. Hasil Estimasi Model ECM Jangka Pendek

\begin{tabular}{|c|c|c|}
\hline Variable & Coefficient & Std. Error \\
\hline C & -0.015050 & 0.045612 \\
\hline $\begin{array}{c}\text { D (Inflasi) } \\
\text { D Pengeluaran Konsumsi } \\
\text { Pemerintah) }\end{array}$ & 0.053583 & 0.000200 \\
\hline D (Hutang Luar Negeri) & 0.006415 & 0.000129 \\
\hline D (Pembiayaan Syariah) & $4.73 \mathrm{E}-05$ & 0.004180 \\
\hline ECT(-1) & -0.538221 & 0.120958 \\
\hline R-squared & 0.897247 & \\
\hline Adjusted R-squared & $\mathbf{0 . 8 5 7 7 2 7}$ & \\
\hline Prob(F-statistic) & $\mathbf{0 . 0 0 0 0 0 5}$ & \\
\hline
\end{tabular}

Sumber: Data diolah, Eviews 10, 2019

Berdasarkan tabel 11 maka diperoleh model ECM jangka pendek sebagai berikut:

$\mathrm{DPE}_{\mathrm{t}}=\alpha_{1} \mathrm{DINF}_{\mathrm{t}}+\alpha_{2} \mathrm{DPKP}_{\mathrm{t}}+\alpha_{3} \mathrm{DHLN}_{\mathrm{t}}+\alpha_{4} \mathrm{DPS}_{\mathrm{t}}$ ECT(-1)

$$
\begin{aligned}
= & -0,015050 \_\mathrm{C}+0,0,053583 \_\mathrm{DINF}+ \\
& 0,000200 \_\mathrm{DPKP}+0,006415 \_\mathrm{DHLN}+ \\
& 0,47305 \_\mathrm{DPS}(-0,538221) \_\mathrm{ECT}
\end{aligned}
$$

Pengaruh inflasi ke pertumbuhan ekonomi (probabilitas $=0,4261)>(\alpha=0,05)$ yang berarti $\mathrm{H}_{0}$ ditolak dengan kata lain hipotesis 1 yang diajukan ditolak atau tidak terbukti berdasarkan data empiris ada pengaruh inflasi terhadap pertumbuhan ekonomi. Pengeluaran konsumsi pemerintah berpengaruh negatif terhadap pertumbuhan ekonomi yang ditunjukkan dengan nilai (probabilitas $=0,1473)>(\alpha$ $=0,05)$. Dengan demikian hipotesis 2 ditolak dan tidak bisa dijadikan model. Hutang luar negeri memiliki pengaruh positif terhadap pertumbuhan ekonomi terbukti dari (probabilitas $=0,0114)<(\alpha=$ $0,05)$. Artinya hipotesis 3 yang berbunyi "hutang luar negeri memiliki pengaruh positif terhadap pertumbuhan ekonomi" diterima dan didukung data empiris. Terakhir, terdapat pengaruh negatif pembiayaan syariah terhadap pertumbuhan ekonomi dibuktikan dari nilai (probabilitas $=0,9912)>(\alpha=$ $0,05)$. Hasil estimasi didapat koefisien variabel ECT (Error Correction Term) yaitu sebesar -0538221 yang mempunyai makna bahwa perbedaan antara tingkat pertumbuhan dengan nilai 1 tahun. Koefisien ECT ini digunakan untuk mengukur respon regressand setiap periode yang menyimpang dari keseimbangan. Menurut Widarjono (2009), koefisien ECT dalam bentuk nilai absolut menjelaskan seberapa cepat waktu yang yang diperlukan untuk mendapatkan nilai keseimbangan. Nilai ECT sebesar -0538221 dengan probabilitas 0,0007 yang berarti signifikan pada tingkat signifikansi 1 persen sehingga model ECM dalam jangka pendek adalah valid atau cukup baik.

\section{PEMBAHASAN}

\section{Pengaruh Inflasi Terhadap Pertumbuhan Ekonomi}

Hasil uji di atas mengindikasikan variabel inflasi dalam jangka pendek berpengaruh positif terhadap pertumbuhan ekonomi. Artinya meningkatnya inflasi akan menaikkan pertumbuhan. Hasil tersebut di atas mengindikasikan bahwa tingkat inflasi mampu menjadi tolok ukur dalam menilai perekonomian suatu negara dalam batas tertentu. Menurut penelitian Susanto \& Rachmawati (Susanto \& Rachmawati, 2013) yang dijadikan dasar oleh Herman (Herman, 2017), bahwa naiknya inflasi dalam persentase yang kecil dapat mendorong produsen untuk meningkatkan produksinya. Sesuai dengan hukum penawaran, jika tingkat harga naik maka penawaran akan naik, hal inilah yang membuat produsen menaikkan hasil produksinya. Persentase inflasi yang rendah tidak mempengaruhi daya beli konsumen karena harga barang masih dijangkau. Kondisi ini yang dapat meningkatkan perekonomian. (Ardiansyah, 2017).

Akan tetapi dalam jangka panjang, inflasi memberi pengaruh negatif bagi pertumbuhan ekonomi. Hasil ini sejalan dengan teori Keynes yang menyatakan dalam jangka pendek kurva penawaran akan bergeser ke kanan (positif), sedangkan dalam jangka panjang kurva penawaran cenderung bergeser ke kiri (negatif). Oleh karena itu, menekan tingkat inflasi menjadi penting untuk meningkatkan pertumbuhan ekonomi. Tetap menjaga tingkat inflasi pada level yang rendah adalah langkah yang harus dilakukan setiap negara dalam menjaga kestabilan perekonomian.

Adapun perkembangan inflasi terhadap pertumbuhan ekonomi Indonesia tahun 2011-2018 dapat dilihat pada gambar di bawah ini:

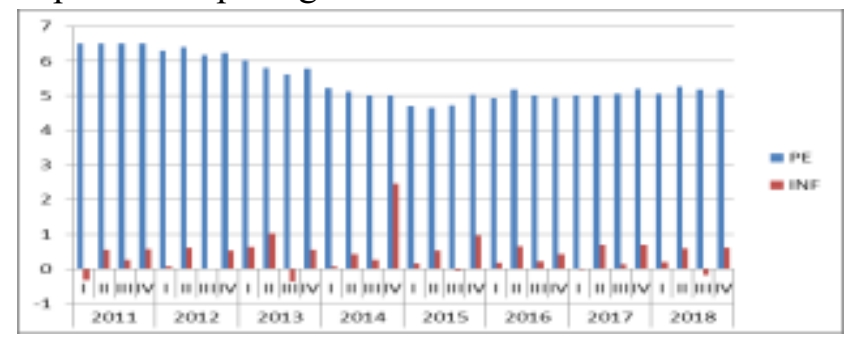

Gambar 3. Perkembangan Tingkat Inflasi dan Pertumbuhan Ekonomi

Sumber: BI, BPS dan publikasi lainnya diolah, 2019 
Laju inflasi Indonesia selama periode 2011-2018 secara umum berfluktuasi, tetapi terkendali. Berdasarkan data rata-rata tingkat inflasi Indonesia masih di bawah 10 persen. Terkendalinya tingkat inflasi ini dipengaruhi oleh struktur ekonomi yang semakin membaik. Berbagai kebijakan moneter diambil pemerintah untuk mengendalikan permintaan masyarakat. Inflasi yang terkendali akan memperkuat daya saing produk di pasar internasional. Sehingga bisa memberikan dampak positf terhadap perekonomian. (BI, 2018).

Adapun faktor utama yang menyebabkan terjadinya inflasi menurut Islam adalah adanya gejolak nilai mata uang. Oleh karena itu solusi yang ditawarkan Islam adalah menjaga tingkat supply dan demand yang terjadi di pasar uang. Karena dalam Islam uang dipandang bukan sebagai komoditas akan tetapi sebagai alat pembayaran atas sejumlah barang yang dibeli. Seyogyanya transaksi di pasar valas seringkali bersifat spekulasi sehingga berpengaruh pada sektor rill yang ditandai tingginya tingkat inflasi. (Zakiyah, 2018).

Tidak banyak ditemukan penelitian yang membahas pengaruh positif inflasi terhadap pertumbuhan ekonomi, , namun ada beberapa penelitian menemukan hasil yang sama di antaranya penelitian yang dilakukan oleh Berlian (Berlian, 2017) yang menganalisis tentang pengaruh inflasi, indeks harga konsumen terhadap PDB di Indonesia pada tahun 2011-2015 (Karlina, 2017). Dalam penelitiannya dia menjelaskan variabel inflasi mempunyai pengaruh positif terhadap pertumbuhan PDB Indonesia tahun 2011-2015. Penelitian G.A dkk (G.A dkk, 2018) juga menemukan hasil yang sama yaitu bahwa tingkat inflasi mempunyai pengaruh positif terhadap pertumbuhan ekonomi.

\section{Pengaruh Pengeluaran Konsumsi Pemerintah Terhadap Pertumbuhan Ekonomi}

Pengeluaran konsumsi pemerintah baik dalam jangka panjang maupun jangka pendek tidak memiliki pengaruh terhadap pertumbuhan ekonomi. Jadi, apabila pengeluaran konsumsi pemerintah meningkat maka akan menurunkan pertumbuhan ekonomi dan sebaliknya apabila pengeluaran konsumsi pemerintah menurun akan meningkatkan pertumbuhan ekonomi.

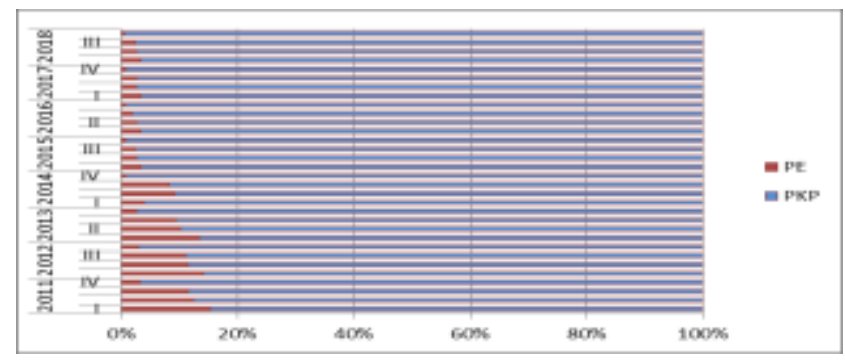

Gambar 4. Perkembangan Pengeluaran Konsumsi Pemerintah dan Pertumbuh Ekonomi

Sumber: BPS dan publikasi lainnya diolah, 2019

Gambar 3 di atas menunjukkan bahwa kontribusi yang diberikan pengeluaran konsumsi pemerintah terhadap pertumbuhan ekonomi masih rendah. Dilihat dari tahun 2011 hingga tahun 2018 kontribusi yang diberikan cenderung menurun yang digambarkan oleh grafik berwarna merah.

Permasalahan yang menjadi sorotan dalam kajian pengeluaran konsumsi pemerintah salah satunya pada aktivitas ekspor-impor. Senyatanya perekonomian yang ditopang oleh impor memiliki jumlah yang lebih tinggi dibanding jumlah ekspor. Tercatat pada tahun 2018 jumlah ekspor Indonesia sebesar 180.059,2 juta dolar AS atau sekitar 609.291,7 ton. Sementara total impor Indonesia pada tahun 2018 mencapai 188.625,6 juta dolar AS atau $171.623,0$ ton. Angka tersebut menunjukkan, jumlah barang masuk ke Indonesia lebih banyak dibanding output yang dihasilkan di dalam negeri. Impor yang tinggi akan memberi dampak negatif bagi perekonomian dalam negeri. Ini disebabkan devisa negara akan berkurang karena pemerintah harus membayar kepada negara eksportir termasuk membayar pajak impor. Perilaku impor yang dilakukan oleh pemerintah mempengaruhi produktivitas di dalam negeri. Sejalan dengan hukum perdagangan internasional, apabila jumlah barang impor semakin naik maka produktivitas di dalam negeri akan menurun. Jika produktivitas menurun korelasinya pada penurunan pertumbuhan ekonomi.

Tantangan dalam hal tata kelola pemerintahan juga menjadi hambatan utama dalam pemberian layanan publik secara efisien, terutama tingkat daerah. Ada perbedaan kinerja yang ekstrem di antara berbagai tingkat pemerintahan dan di antara berbagai daerah. Hal ini dikarenakan kurangnya kapasitas yang dimiliki oleh Pemerintah yang ada di daerah, banyak Pemerintah daerah di Indonesia kesulitan membelanjakan seluruh alokasi anggaran tahunnya karena pengeluaran Pemerintah pusat untuk daerah dialokasikan langsung ke tiga tingkat pemerintahan 
daerah: provinsi, kabupaten/kota, dan desa. Kecamatan didanai dan dikelola di bawah kabupaten/kota. Belum optimalnya pengelolaan transfer dana daerah oleh Pemerintah pusat mengecewakan bagi konstituen, termasuk dunia usaha setempat, dan menghambat Pemerintah pusat baik dalam upaya mengejar prioritas nasional seperti meningkatkan infrastruktur dan juga untuk memberikan stimulus fiskal pada masa perlambatan ekonomi saat ini (OECD, 2018).

Salah satu konsep pengeluaran pemerintah yang bisa diterapkan dalam RAPBN di Indonesia adalah zakat. Salah satu bentuk pengeluaran pemerintah Islam zaman Rasulullah SAW seperti yang diungkap oleh Rahmawati (2008) yaitu penyaluran zakat dan 'ushur kepada yang berhak menerimanya. Langkah ini bertujuan agar tidak terjadi kesenjangan ekonomi dalam masyarakat. Terdistribusinya pendapatan secara merata berimbas pada kesejahteraan tiap-tiap orang di dalam negara tersebut.

Tidak banyak penelitian yang membahas pengaruh negatif pengeluaran konsumsi pemerintah terhadap pertumbuhan ekonomi, namun hasil penelitian ini sejalan dengan penelitian yang dilakukan oleh Naftaly dkk (Naftaly dkk, 2014) yang menyatakan bahwa belanja Pemerintah dalam sektor pendidikan dan pertanian tidak signifikan dengan pertumbuhan ekonomi.

\section{Pengaruh Hutang Luar Negeri Terhadap Pertumbuhan Ekonomi}

Hutang luar negeri dalam jangka panjang berpengaruh negatif terhadap pertumbuhan ekonomi. Jadi, ketika hutang luar negeri meningkat maka pertumbuhan ekonomi akan menurun, sebaliknya jika hutang luar negeri menurun akan meningkatkan pertumbuhan ekonomi. Sedangkan dalam jangka pendek hutang luar negeri mempunyai pengaruh positif terhadap pertumbuhan ekonomi. Artinya hutang luar negeri menyebabkan pertambahan output di dalam negeri.

Secara umum, posisi hutang Indonesia masih dapat dikatakan aman, yaitu di mana rasio-rasio hutang pemerintah yang merujuk pada standar Maastricht Treaty (rasio hutang terhadap PDB) dan rasio jumlah hutang terhadap jumlah penduduk) dinilai dapat menjaga hutang pemerintah dalam batas yang masih dapat dikelola dengan baik (manageable) dan menjamin kesinambungan fiskal. Dibanding dengan beberapa negara berkembang seperti Turki,
Filipina, Thailand, Malaysia dan Brazil, dilihat dari statistik Indonesia mempunyai rasio hutang paling rendah yaitu $28,5 \%$ terhadap PDB. Sedangkan paling tinggi adalah negara Brazil mencapai 81,2\%.

Hutang pemerintah banyak dialokasikan untuk melakukan aktivitas pembangunan, namun saat ini pembangunan infrastruktur oleh Pemerintah masih bersifat statis, yaitu penggunaan infrastruktur lebih besar untuk mengangkut barang-barang hasil impor. Artinya sarana transportasi yang telah dibangun lebih besar penggunaanya untuk memperlancar distribusi barang-barang yang masuk ke Indonesia. Seharusnya pembangunan infrastruktur oleh Pemerintah bersifat dinamis, yaitu merangsang sektor industri dalam negeri. Jika industri dalam negeri berkembang maka pertumbuhan ekonomi juga meningkat.

Pada sisi lain, dampak negatif yang ditimbulkan hutang luar negeri juga tidak kalah besarnya. Semakin besarnya hutang luar negeri akan semakin memberatkan APBN negara, karena hutang-hutang tersebut harus dibayarkan beserta bunganya melalui APBN. Bahkan dikabarkan 52,42\% devisa ekspor habis untuk membayar pokok dan bunga pinjaman investasi dan hutang dagang (Budiawan, 2018).

Salah satu alternatif yang ditawarkan oleh Islam dan sebenarnya telah diterapkan oleh pemerintah namun belum maksimal, yaitu pembiayaan dalam bentuk sukuk. Tahun 2008 adalah kali pertama pemerintah menerbitkan sukuk negara. Sebagai instrument fiskal sukuk ikut andil sebagai penggiat ekonomi nasional. Pada tahun 2008 penerbitan sukuk oleh negara hanya senilai 4,7 triliun rupiah. Kemudian meningkat menjadi 57,09 triliun rupiah di tahun 2012 dan pada tahun 2014 menjadi 75,54 triliun rupiah (Ardi, 2018).

Selain menerbitkan Sukuk Negara, solusi yang bisa dimaksimalkan oleh Indonesia adalah pajak. Umer Chapra dalam kritiknya berpendapat bahwa defisit anggaran negara yang terjadi dapat ditutupi dengan instrument fiskal yaitu pajak dan pengeluaran negara. (Chapra, 1995). Pajak menjadi bagian pendapatan negara dan difungsikan untuk kepentingan rakyat, sehingga alokasi pajak ditujukan untuk melakukan proses pembangunan.

Temuan ini sejalan dengan penelitian sebelumnya seperti Niken \& Dewi (Niken \& Dewi, 2011), Bagus (Bagus, 2017), Syaparuddin dkk (Syaparuddin dkk, 2015), Dedi (Dedi, 2018), Muflihul \& Khair (Muflihul \& Khair, 2016), dan Abdul \& Denny (Abdul \& Denny, 2017). 


\section{Pengaruh Pembiayaan Syariah Terhadap Pertumbuhan Ekonomi}

Pembiayaan syariah dalam jangka panjang maupun jangka pendek tidak mempunyai pengaruh positif terhadap pertumbuhan ekonomi. Apabila pembiayaan syariah meningkat maka pertumbuhan ekonomi akan menurun dan sebaliknya apabila pembiayaan syariah menurun maka akan menaikkan pertumbuhan ekonomi.

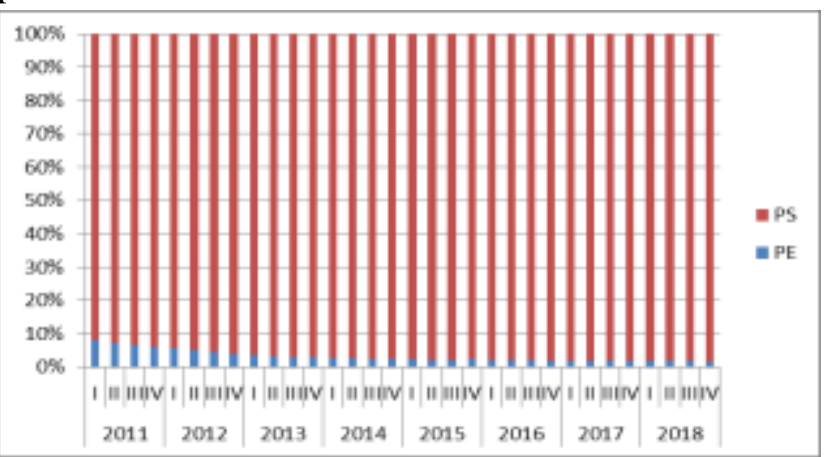

Gambar 4. Perkembangan Pembiayaan Syariah dan Pertumbuhan Ekonomi

Sumber: OJK dan publikasi lainnya diolah, 2019

Berdasarkan gambar 4 di atas dapat dilihat nominal kontribusi yang mampu diberikan oleh bank syariah relatif kecil. Terlihat pada gambar di atas adanya penurunan volume usaha di tiga tahun terakhir sehingga pada akhir tahun 2014 hanya mencatat pertumbuhan sebesar $12 \%$.

Rendahnya kontribusi pembiayaan syariah terhadap pertumbuhan ekonomi disebabkan karena fokus pembiayaan lebih banyak untuk aktivitas konsumsi bukan untuk aktivitas yang produktif. Dapat dilihat dari total pembiayaan pada bank syariah, yaitu pembiayaan murabahah mempunyai total paling tinggi dibanding mudharabah dan musyarakah.

Adapun secara spesifik jika dilihat berdasarkan jenis penggunaan antara pembiayaan modal kerja, investasi dan konsumsi. Total nominal pembiayaan pada aktivitas konsumsi lebih tinggi dibanding penggunaan pada modal kerja dan investasi, di mana komposisi modal kerja hanya 105.055 miliar rupiah pada tahun 2018 dan investasi sebesar 75.730 miliar rupiah, sementara konsumsi mencapai 139.408 miliar rupiah. Padahal modal kerja dan investasi dapat menyumbang output lebih banyak karena sektor cakupannya adalah sektor produktif, di mana penambahan modal kerja akan memudahkan perusahaan dalam mengembangkan produksinya karena modal kerja diperlukan untuk meningkatkan penjualan sehingga apabila penjualan meningkat maka output yang dihasilkan perusahaan juga meningkat. Begitu juga dengan investasi yang memainkan peran strategis dalam menyokong kehidupan ekonomi bangsa. Modal yang terbentuk dari investasi ditujukan untuk proses produksi sehingga akan menghasilkan produk barang dan jasa yang dapat digunakan oleh masyarakat. Di bawah ini perkembangan pembiayaan yang diklasifikasi menurut penggunaan:

Tabel 12. Pembiayaan Berdasarkan Jenis Penggunaan

(Dalam Miliar Rupiah)

\begin{tabular}{|c|r|r|r|}
\hline \multirow{2}{*}{ Tahun } & \multicolumn{3}{|c|}{ Jenis Penggunaan Pembiayaan } \\
\cline { 2 - 4 } & Modal Kerja & Investasi & Konsumsi \\
\hline 2011 & 1.610 & 428 & 551 \\
\hline 2012 & 1.671 & 710 & 888 \\
\hline 2013 & 2.253 & 1.021 & 1.554 \\
\hline 2014 & 4.742 & 1.854 & 2.035 \\
\hline 2015 & 79.949 & 51.690 & 81.357 \\
\hline 2016 & 87.363 & 60.042 & 100.602 \\
\hline 2017 & 99.825 & 66.848 & 119.021 \\
\hline 2018 & 105.055 & 75.730 & 139.408 \\
\hline
\end{tabular}

Sumber: OJK, Statistik Perbankan Syariah, 20112018

Perannya yang belum optimal dalam mendukung pertumbuhan ekonomi perlu menjadi perhatian baik oleh pemerintah maupun institusi keuangan. Dalam pelaksanaan operasionalnya harus dilakukan revitalisasi kebijakan agar fokus pengalokasian pembiayaan bertumpu pada sektor rill, seperti pengembangan ke sektor produktif yang memiliki multiplier effect tinggi antara lain pertanian, industri pengolahan, energi dan sektor UMKM. Dengan demikian pengembangan berbagai bidang ekonomi dapat terlaksana.

Peneliti belum menemukan penelitian yang membahas pengaruh negatif pembiayaan syariah terhadap pertumbuhan ekonomi. Akan tetapi berdasarkan outlook perbankan syariah yang dirilis oleh OJK menyebutkan masih banyak hal-hal yang perlu dibenahi dalam rangka pengembangan perbankan syariah seperti yang sudah dipaparkan di atas.

\section{KESIMPULAN}

Kesimpulan dari penelitian adalah bahwa dalam jangka panjang keempat variabel penelitian dalam hal ini inflasi, pengeluaran konsumsi pemerintah, hutang luar negeri, dan pembiayaan syariah tidak memiliki pengaruh terhadap pertumbuhan ekonomi. 
Artinya apabila tingkat inflasi, pengeluaran konsumsi pemerintah, hutang luar negeri, dan pembiayaan syariah meningkat, maka pertumbuhan ekonomi justru menurun.

Sementara dalam jangka pendek diperoleh dua variabel yang memiliki pengaruh terhadap pertumbuhan ekonomi, yaitu inflasi dan hutang luar negeri. Artinya tingkat inflasi yang naik dalam batas wajar dapat dijadikan tolak ukur dalam menilai suatu perekonomian. Begitupun hutang luar negeri dalam jangka pendek dapat menyebabkan pertambahan output di dalam negeri. Namun karena pertambahan yang diberikan masih sangat rendah, sehingga pemerintah harus berhati-hati dalam mengambil kebijakan terkait hutang luar negeri.

Sebagai regulator, pemerintah perlu menetapkan dan mengontrol regulasi untuk menekan angka inflasi di Indonesia karena inflasi yang tinggi berimplikasi negatif terhadap pertumbuhan ekonomi nasional. Kemudian melakukan koordinasi agar pendistribusian anggaran dilakukan secara adil dan merata. Pengelolaan zakat secara maksimal juga bisa menjadi solusi bagi pemerintah dalam menyelesaikan berbagai permasalahan ekonomi dalam tataran kesejahteraan. Pemerintah pun perlu mengurangi ketergantungan terhadap hutang luar negeri dengan memanfaatkan berbagai potensi modal dalam negeri, yaitu menggaet investor dalam negeri dalam berbagai sektor produktif, yaitu memperbanyak investasi sukuk baik oleh negara maupun swasta. Dalam hal ini perbankan yang menjadi jantung bagi tumbuhnya berbagai usaha dalam negeri harus lebih fokus pada sektor rill bukan untuk kegiatan konsumsi agar percepatan pembangunan dapat terlaksana dan ekonomi Indonesia terus tumbuh.

Merangkum dari hasil penelitian yang sudah dilakukan, maka dapat dikatakan penelitian ini berbeda dengan penelitian lainnya yang relevan. Perbedaan dengan penelitian sebelumnya bisa dilihat dari Judul Penelitian, Problem, Kerangka Teori, Metode Analisis, dan Hasil Penelitian. Pada penelitian ini menganalisis tentang Pertumbuhan Ekonomi dan faktor-faktor yang mempengaruhi, yaitu diambil dari empat variabel penting: Inflasi, Pengeluaran Konsumsi Pemerintah, Hutang Luar Negeri, dan Pembiayaan Syariah. Selanjutnya variabel-variabel tersebut diuji menggunakan Eviews 10 dengan metode Error Correction Model (ECM). Namun perbedaan yang paling mendasar dengan penelitian-penelitian sebelumnya adalah menjadikan teori Ekonomi Islam sebagai alat analisa terhadap pertumbuhan ekonomi. Jika penelitian sebelumnya dikupas melalui sudut pandang ilmu ekonomi konvensional, penelitian peneliti memasukkan teori keIslaman sebagai pisau bedah dalam kajian penelitian saat ini.

\section{REFERENSI}

Almizan. (2016). Pembangunan Ekonomi dalam Perspektif Ekonomi Islam. Maqdla: Jurnal Kajian Ekonomi Islam.

Ardi, Muhammad. (2018). Pengaruh Sukuk Terhadap Pertumbuhan Ekonomi Indonesia. IQTISHADUNA.

Ardiansyah, H. (2017). Pengaruh Inflasi Terhadap Pertumbuhan Ekonomi Di Indonesia. Jurnal Pendidikan Ekonomi (JUPE).

Astuti, W. (2015). Pengaruh Pembiayaan Syariah Terhadap Pertumbuhan Ekonomi di Sumatera Utara. The $8^{\text {th }}$ International Workshop on Islamic Development.

Azwar. (2016). Peran Alokatif Pemerintah Melalui Pengadaan Barang/Jasa dan Pengaruhnya Terhadap Perekonomian Indonesia. Kajian Ekonomi \& Keuangan.

Badan Pusat Statistik. (2019). Produk Domestik Bruto. http://www.bps.go.id/subject/11/produkdomestik-bruto--lapangan-usaha-.html.

Bank Indonesia. (2018). Laporan Perekonomian Indonesia 2018.

Budiawan, A. (2018). Utang Pemerintah Ekonomi Politik Kebijakan Fiskal. Seminar Nasional Menyikapi Polemik Utang Pemerintah Indonesia.

Chapra, M. U. (1995). Islam and The Challenge, The Islamic Foundation and The International Institut of Islamic Though, Jakarta: Gema Insani Press \& Tazkia Institute.

Danawati, S. dkk. (2016). Pengaruh Pengeluaran Pemerintah dan Investasi Terhadap Kesempatan Kerja, Pertumbuhan Ekonomi Serta Ketimpangan Pendapatan Kabupaten/Kota di Provinsi Bali. E-Jurnal Ekonomi dan Bisnis.

Deti, S. dkk. (2017). Kontribusi Perbankan Syariah Terhadap Pertumbuhan Ekonomi di Kabupaten Sambas. Jurnal Diskursus Islam.

Fadilla. (2017). Perbandingan Teori Inflasi dalam Perspektif Islam dan Konvensional. Islamic Banking. 
Fitria, T. N. (2016). KONTRIBUSI EKONOMI ISLAM DALAM PEMBANGUNAN EKONOMI NASIONAL. JURNAL ILMIAH EKONOMI ISLAM. https://doi.org/10.29040/jiei.v2i03.3

Fatturroyhan. M. A. (2017). Pembiayaan Defisit APBN Menurut Umer Chapra (Studi Analisa Kritik Terhadap Pembiayaan Defisit APBN Indonesia Periode 2010-2015). CAKRAWALA: Jurnal Studi Islam.

G.A. A. dkk. Analysis of Inflation and Its Effect on Economic Growth in Nigeria. IOSR Journal of Economics and Finance (IOSR-JEF).

Gempito. (2010). Pemikiran Kebijakan Fiskal Ekonomi Islam, JURIS.

Handayani, R. (2015). Analisis Pengeluaran Pemerintah Sektor Pendidikan dan Kesehatan Terhadap Indeks Pembangunan Manusia di Provinsi Riau. Jom FEKON.

Ilyas, R. (2015). KONSEP PEMBIAYAAN DALAM PERBANKAN SYARI'AH. JURNAL PENELITIAN.

https://doi.org/10.21043/jupe.v9i1.859

Junaedi, D. (2018). Hubungan Antara Utang Luar Negeri dengan Perekonomian dan Kemiskinan: Komparasi Antarezim Pemerintahan", Simposium Nasional Keuangan Negara.

http://www.jurnal.bppk.kemenkeu.go.id/snkn/article/ view/154.

Karim, A. A. (2014) Ekonomi Makro Islam (Edisi 3), Jakarta: Rajawali Pers.

Karlina, B. Pengaruh Tingkat Inflasi, Indeks Harga Konsumen Terhadap PDB di Indonesia pada Tahun 2011-2015. Jurnal Ekonomika dan Manajemen.

Kementrian Keuangan Republik Indonesia. Capaian Pembangunan Infrastruktur Indonesia.

http://www.kemenkeu.go.id/publikasi/berita/,

Khair, M., \& Rusydi, B. U. (2016). E Cce a Ce F Ca. Economics, Sosial, and Development.
Marina., A. K. (2016). Analisis Pengaruh Tingkat Inflasi dan Jumlah Uang Beredar Terhadap Nilai Tukar Rupiah di Indonesia. Ecces: Ecconomics, Social, and Development studies.

Lusbis, I. F. (2014). Analisis Hubungan Antara Inflasi dan Pertumbuhan Ekonomi: Kasus Indonesia. Quantitative Economics Journal.

MS, M. Z. (2017). PENGARUH PENGELUARAN PEMERINTAH TERHADAP PERTUMBUHAN EKONOMI DI PROVINSI JAMBI. EKONOMIS : Journal of Economics and https://doi.org/10.33087/ekonomis.v1i1.18

Muhajirin. (2015). Konsep Hutang Negara dalam Perspektif Hukum Ekonomi Islam (Studi Analisis Antara Konsep Anggaran Balance Budget dengan Defisit Budget). Al Mashlahah Jurnal Hukum dan Pranata Sosial Islam.

Muttaqin, R. Pertumbuhan Ekonomi dalam Perspektif Islam. Maro, Jurnal Ekonomi Syariah dan Bisnis.

OECD Economic Survey. (2018) Survey Economi OECD Indonesia 2018. http://www.oecd.org,

Rahmawati, L. (2008). Kebijakan Fiskal dalam Islam. Al-Qanun.

Romi, S., \& Umiyati, E. (2018). Pengaruh Pertumbuhan Ekonomi dan Upah Minimum terhadap Kemiskinan di Kota Jambi. E-Jurnal Perspektif Ekonomi Dan Pembangunan Daerah.

Septiatin, A. dkk. (2015). Pengaruh Inflasi dan Tingkat Pengangguran Terhadap Pertumbuhan Ekonomi di Indonesia. I-Economic.

Syaparuddin, dkk. (2015). Pengaruh Hutang Luar Negeri Terhadap Pertumbuhan Ekonomi Indonesia, Thailand, Malaysia, Fhilipina, Vietnam dan Burma Periode 1990-2013. Jurnal Paradigma Ekonomika.

Terminanto, A. A., \& Ali R. (2017). Pengaruh Belanja Pemerintah dan Pembiayaan Bank Syariah Terhadap Pertumbuhan Ekonomi: Studi Kasus Data Panel Provinsi di Indonesia. IQTISHADIA.

Zakiyah, K. (2018). Peran Pengendalian Inflasi dalam Tinjauan Perspektif Al-Qur'an. The International Of Applied Business (TIJAB). 